Journal of Advanced College of Engineering and Management, Vol. 4, 2018

\title{
CRITICAL SUCCESS FACTORS OF PROJECT MANAGEMENT IN NEPALESE HYDROPOWER PROJECTS
}

\author{
Raju Thapa ${ }^{1}$, Santosh Kumar Shrestha ${ }^{2}$ \\ ${ }^{1}$ Department of Civil Engineering, Pulchowk Campus, \\ ${ }^{2}$ Lecturer, Department of Civil Engineering, Pulchowk Campus
}

\begin{abstract}
The delay in the construction industry is a global phenomenon and the construction industry in Nepal can't be the exception. To deliver the project product on time, within the budget, of quality in the safest manner is the goal of project management. Even potentially good projects are failing because of the weak project management performance in Nepalese construction projects. Due to the lack of research based findings in these areas, the new project managers are facing problems about in which areas they need to focus for successful delivery of the project. The purpose of this research is to find out the critical success factors of project management that help the project parties reach their goal as planned in Nepalese hydropower projects. In this study, general success factors of project management were collected from various literatures and the pilot survey, rank them based on relative importance index (RII), and found top seven success factors as critical success factor. Based on the 85 responses from project managers and experts working in hydropower projects in the first stage study, top seven success factors of project management were Effective communication between project team members (S1), Job satisfaction of project team members (S2), Timely decision by client (S3), Competence of the project manager (S4), Effective coordination between stakeholders, public institutions (S5), Competence of the project team members (S6), Proper and timely supervision (S7).
\end{abstract}

Key words: Project success, Project management success, Critical success factors

\section{Introduction}

A review of the project management literature provides no consistent interpretation of the term "project success". The criteria for measuring project success must be set out at the beginning of the project, otherwise different stakeholders will have different interpretation about whether the project failed or succeeded (Baccarini, 1999). David Baccarini uses the Logical Framework Method (LFM) for defining and understanding project success in which two components of project success are identified: Project management success and Project product success. Project management success focuses on delivering the project product on time, within the budget, of quality in the safest manner while Project product success focuses on long term objectives of the project like profitability, user's satisfaction etc.

Over the time it has been shown that project management and project success are not necessarily directly related. The objectives of both project management and the project are different and the control of time, cost and progress, which are often the project management objectives, should not be confused with measuring project success. There are many examples of projects which are relatively successful despite not being completed on time, or being over budget e.g. the Thames Barrier, the Fulmar North Sea oil project because they met the higher and long term objectives (Munns \&Bjeirmi, 1996). The project success and failure is not totally dependent on project management success and failure, the exception being when the project product is delivered too late or too expensive and can no longer be used. Poor project management could threaten a potentially good project. Successful project management techniques will contribute to the achievement of project success but the project management success alone can't prevent it from failing. The right project will succeed almost without the success of project management but successful project management could enhance its success. Selecting the right project at the outset after screening potentially unsuccessful project and successful 
project management (delivering project successfully) certainly ensure total project success (Munns \& Bjeirmi, 1996).

In Nepal, many hydropower projects (project product) especially public projects are not delivered successfully which has threaten the success of potentially good projects. The projects identified are potentially good but the failure in project delivery process (project management) is the main problem in Nepal. The average cost per MW. is NRs 35,41,84,312.61 for Public Hydropower project and NRs $18,56,45,840.61$ for Private Hydropower project which is almost double (Maharjan, 2016). The delay in projects like Kulekhani-III, Chameliya, Upper Trishuli 3A shows weak project performance in Nepal. This shows the project management issues is extremely poor in Nepalese construction sector. So it's essential to research project management success factors which could especially help new project managers which will improve project management performance in Nepal there by leading to something better in Nepalese construction industry.

Success factors are those inputs to project management system which increase the likely hood of success. This article is focused on the project management success factors only in Nepalese hydropower projects and not the project success as whole.

\section{Objective}

The objectives of this study was to find out the critical success factors of project management in Nepalese hydropower projects. This will be achieved by questionnaire survey of the project managers and engineers from client, consultant, contractor involved in hydropower projects under construction phase as listed in Department of Electricity Development (DOED) official website.

\section{Research Methodology}

First of all, the literature related to project and project management success were collected and thoroughly reviewed, the important project management related success factors were collected and a questionnaire was prepared in which respondents were asked to rate the importance of the particular success factors in five point Likert scale ( $5=$ Very Important, $4=$ Important, $3=$ Moderately important, $2=$ Slightly important, $1=$ Not Important) based on their experience. The pilot survey was conducted in which the respondents were asked to add the factors missed in the questionnaire and any comments regarding the questionnaire. From the response of 17 respondents in the pilot survey from client, consultant and contractor, the reliability of five point scale was tested by Cronbach's coefficient alpha " $\alpha$ " which was found to be .9 , so reliability was acceptable, and final modification was done in the questionnaire for the main survey.

There were altogether thirty six success factors in the questionnaire after adding some factors from pilot survey. The first section of the questionnaire was related to the general information of the respondents, one question to test the reliability of survey was added. Did you read and rank these factors carefully? If so, select "Not at all". Then the main survey was conducted. The questionnaire were distributed through google form as well as visiting the respondent's office. Among the 140 questionnaire distributed, 87 response were received. Among the 87 response received, two of them failed the reliability test and hence discarded so only 85 responses were used for further analysis.

\section{Data Analysis}

There were 37 Female and 48 male respondents. Among them 28 responses were from client, 25 responses were from consultant and 32 responses were from contractor. Other characteristics of respondents are as follow: 


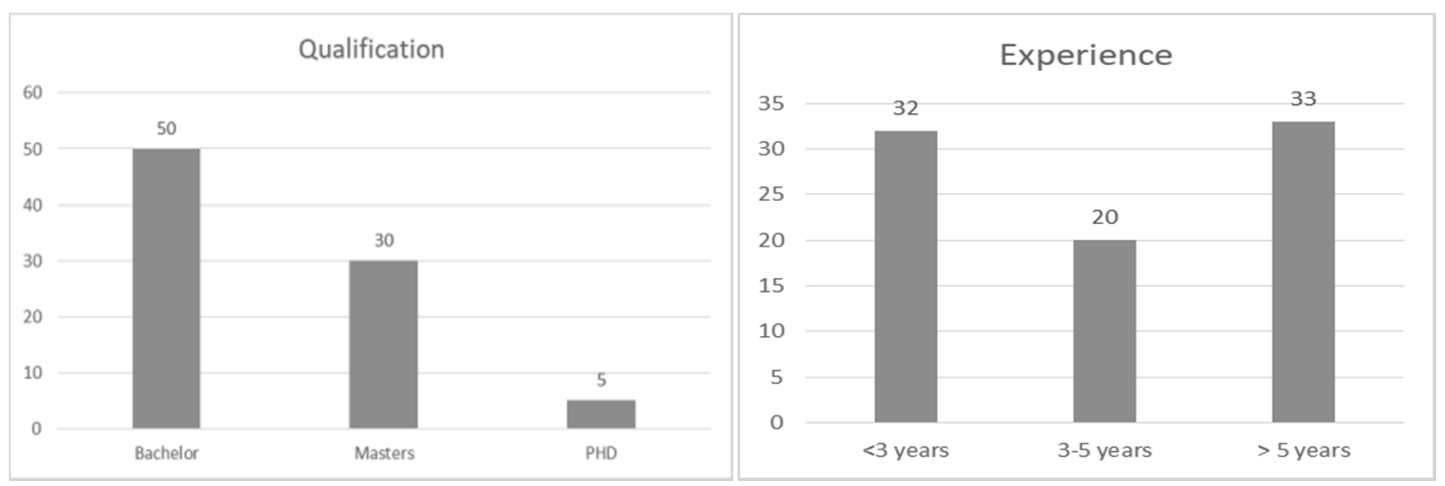

The Relative Importance Index (RII) is a statistical parameter to determine the ranking of different factors based on the importance level or ratings responded by the respondents. For $\mathrm{n}^{\text {th }}$ point Likert Scale, RII is computed as follow:

$$
R I I=\frac{\sum i i==n 1(A i * N i)}{A * N}
$$

Where, $R I I=$ Relative Importance Index for $\mathrm{n}^{\text {th }}$ point Likert Scale.

$n=$ number of points in Likert Scale used $A=$ highest weight of the Likert Scale

$$
\begin{aligned}
& N=\text { total respondents } \\
& N_{i}=\text { weight of } \mathrm{i}^{\text {th }} \text { rating }
\end{aligned}
$$

For five point Likert Scale $(\mathrm{n}=5)$, the equation becomes:

$$
R I I=\frac{\sum i i==51(A i * N i)}{5 * N}
$$

This equation was used to calculate the relative importance index (RII) of each success factors and based on the RII, ranking was done.

\section{Results}

Among the thirty six success factors of project management, the top seven success factors taken as critical success factors as per client's response only is as follow.

- Motivation/job satisfaction of project team members

- Competence of the project manger

- Effective communication between project team members

- Project team members' goal commitment

- Timely decision by client

- Competence of the project team members

- Top management support

As per the response of the consultant only, the critical success factors of project management are as follow.

- Timely decision by client

- Effective communication between project team members 
- Motivation/job satisfaction of project team members

- Project risk management plan

- Time, cost, quality control mechanism (for monitoring and controlling project progress)

- Timely settlement of claim

- Competence of the project manger

While the analysis of the contractor's response only, gives the following critical success factors.

- Effective communication between project team members

- Timely decision by client

- Effective coordination between stakeholders, public institutions

- Top management support

- Motivation/job satisfaction of project team members

- Competence of the project team members

- Competence of the project manger

After this, Kendall's coefficient of concordance, represented by the symbol w, was found using SPSS software to measure for assessing agreement among raters. The value of correlation was found to be .886 between overall ranks, .891 between Client's and Consultant's ranking, .944 between Client's and Contractors' and .909. This shows that the raters are in agreement and hence the overall analysis (client, consultant and contractor combined) of the success factors gives the following critical success factors.

- Effective communication between project team members (S1) (RII=0.898)

- Motivation/job satisfaction of project team members (S2) $(\mathrm{RII}=0.889)$

- Timely decision by client (S3) (RII=0.885)

- Competence of the project manager (S4) $(\mathrm{RII}=0.887)$

- Effective coordination between stakeholders, public institutions (S5) (RII=0.861)

- Competence of the project team members (S6) $(\mathrm{RII}=0.860)$

- Proper and timely supervision (S7) (RII=0.851)

\section{Conclusion and Discussion}

Communication is the most important during implementation. When there is communication gap between the project team members, different problem arises. The overall result of the analysis shows that "Effective communication between project team members (S1)" as first ranked success factors. In Nepal, there is lack of motivation and job satisfaction which result in poor productivity. Many literature about job satisfaction favors this. In this study, it has been ranked second which is interesting. "Timely decision by client (S3)" is found to be third ranked. Due to the delay in decision various disputes, problems arises hampering the project implementation process. Appointing a competent project managers is very important and the result shows "Competence of the project manager (S4)" as fourth ranked. A competent project managers need various technical, managerial, leadership skills, motivating personality, emotional intelligence etc. During implementation of any project, the project team has to consult many government bodies, departments, organizations and sometimes duplication of works takes place. Due to unnecessary procedural activities, the project implementation process is hampered. So, "Effective coordination between stakeholders, public institutions (S5)" is important success factors ranked in the fifth position. "Competence of the project 
team members (S6)" ranked in sixth position is also important for implementation process. "Proper and timely supervision (S7)" has been ranked in seventh position which is very important to avoid unnecessary claims, disputes, errors in implementation process etc.

\section{References}

1. Baccarini, D. (1999). "The Logical Framework Method for Defining Project Success". Project Management Journal , 25-32.

2. Didenko, I., \&Konovets, I. (2008). "Success Factors in Construction Project: A Study of Housing Projects in Ukraine".

3. Gar, K. K. (2015). "Critical Success Factors of Project Management for Dam Construction Projects in Myanmar”.

4. Munns, A., \& Bjeirmi, B. (1996). "The role of project management in achieving project success". International Journal of Project Management, 14, 81-87.

5. Salleh, R. (2009). "Critical Success Factors of Project Management For Brunei Construction Projects: Improving Project Performance".

6. Shakya, S., Shrestha, R. B., Shrestha, T., \&Rajbhandry, Z. (2016). “A Study of Nepal's Hydropower Sector". New Baneshwor: Transparency International.

7. Thapa Magaar, R. (2018). "Critical Success Factors of Project Management in Nepalese Hydropower Projects." 